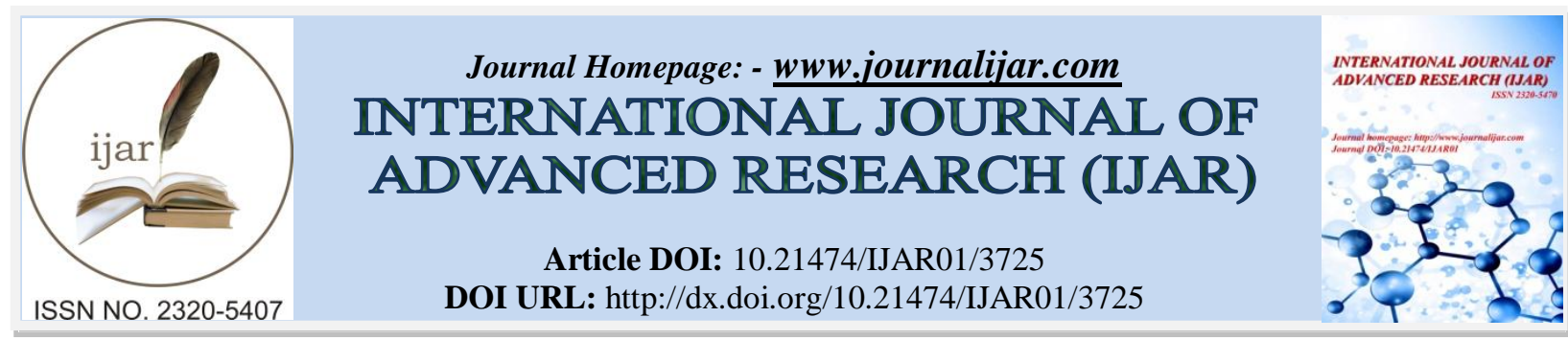

RESEARCH ARTICLE

\title{
IN VITRO EFFICACY OF TRICHODERMA ISOLATES AGAINST SOME FUNGI CAUSING FUNGAL ROT DISEASE OF TOMATO.
}

Jahangir Abdullah Koka*, Abdul Hamid Wani, Mohd Yaqub Bhat and Shazia Parveen.

Section of Mycology and Plant Pathology, Department of Botany, University of Kashmir, Hazratbal, Srinagar, Kashmir.

\section{Manuscript Info}

Manuscript History

Received: 01 January 2017

Final Accepted: 11 February 2017

Published: March 2017

Key words:-

Tomato, Trichoderma isolates, Alternaria alternata (Fr.) Keissl,

Penicillium sp., Aspergillus niger Van Tiegh,

\begin{abstract}
Biological control has been found efficient eco-friendly approach for the management of several fungal diseases caused by pathogenic fungi. Therefore, present study was carried out to evaluate the in vitro efficacy of some Trichoderma isolates against the pathogenic fungi, Alternaria alternata (Fr.) Keissl., Penicillium sp and Aspergillus niger Van Tiegh known to infect tomato fruits in Kashmir. It was observed from the results that all the Trichoderma isolates brought about significant inhibition in the mycelial growth. The inhibition in mycelial growth of Alternaria alternata, by PPT3 isolate of Trichoderma was $26.79 \%$, followed by isolate PPT1 (19.47\%) and isolate PPT2 (14.64\%) of Trichoderma respectively. Likewise, the highest inhibition in mycelial growth of Penicillium sp. was shown by isolate PPT3 (34.36\%) followed by isolate PPT2 $(23.44 \%)$ and by isolate PPT1 (9.37\%) respectively. In case of Aspergillus niger, the inhibition in mycelial growth was highest by isolate PPT3 $(42.5 \%)$ followed by isolate PPT1 $(36.67 \%)$ and by isolate PPT2 (31.67) respectively. The results indicate that different local isolates of Trichoderma proved effective against the tested pathogenic fungi and can be evaluated further for their antifungal activity against other fungi.
\end{abstract}

Copy Right, IJAR, 2017,. All rights reserved.

\section{Introduction:-}

Tomato (Lycopersicon esculentum Mill.) is a member of the family Solanaceae which comprises short-lived perennial herbaceous plants. It is one of the most popular vegetable crops widely grown for its edible fruits, high nutritive values and also for its diversified uses (Afroz et al., 2008; Ewulo et al., 2008). They are important source of vitamins and important cash crop for both small holders and medium scale commercial farmers (Ana et al., 2003). The fruit also contains plenty of antioxidant carotenoid lycopene that has recently attracted interest because of its role in preventing cancer heart disease and muscular degeneration (Wener, 2008). Several pathogenic fungi are known to cause damage to tomato especially under storage conditions and also on the aerial parts of the plants. The main postharvest disease of tomato caused by various pathogenic fungi are Rhizopus stolonifer (Stevens et al., 1997; Schena et al., 1999), Botrytis cinerea (Lee et al., 2006) and Alternaria alternata (Feng and Zheng, 2007). A. alternata is a saprophytic pathogen of tomato causing postharvest black rot at high frequency (Akhtar et al. 1994). Harvested fruits and vegetables decay due to fungal infestation is the main cause of major losses in food production. Postharvest decay of fruits and vegetables can be traced to infections, occur either between flowering and fruit maturity or during harvesting and subsequent handling and storage (Eckert and Ogawa 1988). The loss resulting

Corresponding Author:- Jahangir Abdullah Koka.

Address:- Section of Mycology and Plant Pathology, Department of Botany, University of Kashmir, 
from these infections have been reduced primarily by applying fungicides in the field or after harvest (Eckert and Ogawa 1988).

Trichoderma spp. is the most widely studied biocontrol agents (BCAs) against plant pathogens because of their ability to reduce the population of soil borne plant pathogens (Papavizas, 1985). They are soil borne fungi and show significant activity against a wide range of plant pathogenic fungi (Elad et al., 1982). Mechanism used by Trichoderma spp. for control of plant pathogen includes competition, mycoparasitism, antibiosis and induced resistance of the plant host (Chet, 1987; Schirmbock et al., 1994).

Trichoderma is one of the common fungal biocontrol agent is being used worldwide for suitable management of various foliar and soil borne plant pathogens. (Dominguesa et al., 2000). Therefore, the objective of the present investigation was to assess the efficacy of local isolates of Trichoderma under in vitro condition against some fungal pathogens isolated from tomato fruits.

\section{Materials and Methods:-}

Tomato (Lycopersicon esculentum Mill.) fruits were obtained from different vegetable local markets of Kashmir Valley. Samples of infected fruits were brought to the laboratory in clean polythene bags and these samples were either used immediately or stored at $10^{\circ} \mathrm{C}$ in the laboratory for different pathological studies. Small portions of rotted tissues were isolated aseptically from the diseased tomato fruits and transferred to Potato Dextrose Agar (PDA) medium. Pure colony cultures were obtained by sub-culturing the isolated fungi such as Alternaria alternata (Fr.) Keissl., Penicillium sp and Aspergillus niger Van Tiegh, in separate Petri plates containing the same medium. The pathogen was identified by their morphological, reproductive and cultural characteristics (Ellis, 1971; Barnett and Hunter, 1972; Watanabe, 2002; Gilman, 2008). For pathogenicity, pathogens were re-inoculated after isolation onto the healthy pear fruits (Tomkin and Trout, 1931). Then all the fruits were kept in clean polythene bags and incubated at $25+2^{\circ} \mathrm{C}$ for ten days. These pathogenicity tests were used for the identification of plant pathogens and to confirm the detection of a particular disease. Identification of the disease and the pathogen was done following Koch's postulates.

Isolates of Trichoderma were isolated from rhizospheric soil of the tomato plant following serial dilution method (Brown 2004). These isolates were identified on the basis of morphological and cultural characteristics and named as PPT1, PPT2 and PPT3. The antimycotic effect of these pure local isolates of Trichoderma against isolated fungi such as Alternaria alternata (Fr.) Keissl., Penicillium sp and Aspergillus niger Van Tiegh was assessed by dual culture method (Bashar and Rai 1994, Prince et al. 2011). To assess the effect of Trichoderma isolates against fungi, known quantity of mycelia of both was inoculated onto petriplates containing PDA. Then the inhibition in mycelial growth of fungi such as Alternaria alternata (Fr.) Keissl., Penicillium sp and Aspergillus niger Van Tiegh by isolates of Trichoderma was observed after incubation. The percent inhibition in mycelial growth of tested fungal pathogens in presence of Trichoderma isolates was calculated as per the formula given by Skidmore and Dickinson 1976.

Mycelial growth inhibition $(\%)=\frac{\mathrm{dc}-\mathrm{dt}}{\mathrm{dc}} \times 100$

Where $\mathrm{dc}=$ average diameter of fungal colony in control, and $\mathrm{dt}=$ average diameter of fungal colony in treatment group.

\section{Results:-}

It was observed from the results (Table 1) that isolate PPT-3 of Trichoderma inhibited the mycelial growth of Alternaria alternata to an extent of 26.79 per cent. This was followed by Trichoderma isolates PPT-1 (19.47\%) and PPT-2 (14.64\%) respectively. Likewise, growth inhibition of Penicillium sp by Trichoderma isolates PPT-1 was $9.37 \%$, by PPT-2 was $23.44 \%$ and by PPT-3 was $34.36 \%$ respectively and inhibition in mycelial growth of Aspergillus niger due to Trichoderma isolates, PPT1, PPT2 and PPT3 were 36.67\%, 31.67\% and 42.5\% respectively.

The maximum growth inhibition of Alternaria alternata and Aspergillus niger was due to Trichoderma isolate, PPT3 followed by isolate PPT1 and isolate PPT2 respectively. Whereas, isolate PPT3 caused maximum growth inhibition of Penicillium sp. However, the least inhibition in mycelial growth of pathogenic fungi was observed by Trichoderma isolate, PPT1. 
Table 1:- Effect of Trichoderma isolates on the mycelial growth of fungi causing rot disease of tomato by dual culture plate method

\begin{tabular}{|l|c|l|c|}
\hline \multirow{2}{*}{ Treatment } & \multicolumn{3}{|c|}{ Mycelial growth (mm) } \\
\cline { 2 - 4 } & Alternaria alternata & Penicillium sp & Aspergillus niger \\
\hline PPTI & $11.00 \pm 1.00$ & $19.33 \pm 1.15$ & $25.33 \pm 1.52$ \\
& $(19.47 \%)$ & $(9.37 \%)$ & $(36.67 \%)$ \\
\hline PPT2 & $11.66 \pm 1.52$ & $16.33 \pm 1.52$ & $27.33 \pm 2.08$ \\
& $(14.64 \%)$ & $(23.44 \%)$ & $(31.67 \%$ \\
\hline PPT3 & $10.00 \pm 1.00$ & $14.00 \pm 1.00$ & $23.00 \pm 2.00$ \\
& $(26.79 \%)$ & $(34.36 \%)$ & $(42.5 \%)$ \\
\hline Control & $13.66 \pm 1.52$ & $21.33 \pm 1.52$ & $40.00 \pm 1.00$ \\
\hline
\end{tabular}

Each value is mean of 3 replicates $\pm \mathrm{SD}$

Figures in parenthesis is the mycelial growth inhibition (\%)

\section{Discussion:-}

It is clear from the above results that different local isolates of Trichoderma caused significant inhibition in mycelial growth of Alternaria alternata (Fr.) Keissl., Pencillium sps and Aspergillus niger van Tiegh.

In a similar studies, the antagonistic activities of Trichoderma harzianum against several pathogenic fungi have been reported by many workers (Henis and Chet, (1975); Backman and Rodrigues-Kabana, 1974; Hadar et al., 1979 and Elad et al., 1980). Kakde and Chavan (2011) studied the antagonistic activity of Trichoderma viride and Trichoderma harzianum against storage fungi and found that growth of Curvularia lunata, Rhizopus stolonifer, Fusarium oxysporum, Macrophomina phaseolina and Penicillium chrysogenum was retarded due to Trichoderma species. Dharmaputra et al. (1994) also tested two isolates of T. harzianum and one isolates of $T$. viride against Ganoderma and found that all isolates inhibited the mycelial growth of the pathogen, but $T$. harzianum (isolates B 10-1) showed the best performance. Etabarian (2006) reported that T. viridi (MO) reduced the colony area of Macrophomina phaseoli by 19.2 and $34.9 \%$ using the dual culture and cellophane methods, respectively. Intana $e t$ al. (2007) reported the efficacy of three mutant and two wild type strains of T. harzianum against Colletotrichum capsicis, causal agent of anthracnose of chili. The present study suggests that Trichoderma sp. effectively inhibits the growth of fungi causing rot of tomato, hence can be used as a biocontrol agent against rot diseases of vegetables. Bashar and Rai (1994) studied the three isolates of Trichoderma viz.,Trichoderma harzianum Refai, Trichoderma hamatum and $T$. viride Pers. were selected to test their antagonistic potential against the pathogens following dual culture technique. However, further investigation is needed for the efficacy of these local isolates of Trichoderma against fungal pathogens.

\section{Acknowledgement:-}

The authors are highly thankful to the Head Department of Botany, University of Kashmir for providing the necessary facilities for the smooth research.

\section{References:-}

1. Afroz M, Ashrafuzzamani M, Ahmed MN, Ali ME, Azim MR: Integrated management of major fungal disease of tomato. International Journal of Sustainable Crop Production 2008, 3(2):54-59.

2. Akhtar KP, Matin M, Mirza JH, Shakir AS, Rafique M: Some studies on the post harvest diseases of tomato fruits and their chemical control. Pak J Phytopathol. 1994. 6:25-129.

3. Ana MV, Abdurrabi S, Benhard L: A Guide to integrated Pest Management in Tomato Production in Easthern and Southern Africa. ICIPE Science Press, Nairobi, Kenya. 2003,144Pp

4. Backman PA, Rodriguez-kabana R: A system for the growth and delivery of biological control to the soil. Phytopathology, 1974, 65:819-821.

5. Barnett HL, Hunter BB: Illustrated genera of Imperfect Fungi. Burgess Publishing Company, Third edition. 1972, pp. 241.

6. Bashar MA, Rai B: Antagonistic potential of root-region microflora of chickpea against Fusarium oxysporum f. sp. ciceri. Bangladesh J. Bot. 1994, 23(1): 13-19.

7. Brown AE: Benson's Microbiological Applications: Laboratory Manual in General Microbiology. McGraw Hill, New York. 2004, pp. 432.

8. Chet I: Trichoderma: Application, mode of action, and potential as a biocontrol agent of soil-borne plantpathogenic fungi. in: Innovative Approaches to Plant Disease Control. 1987, 137- 160. 
9. Dharmaputra OS, Purba RY, Sipayung A: Research activities on the biology and control of Ganoderma at Seameo Biotrop and Iopri Marihat. In: Holderness M. (Eds): Proceedings of first international workshop on perennial crop diseases caused by Ganoderma. Universiti Pertanian, Selangor, Malaysia. 1994.

10. Dominguesa FC, Queiroza JA, Cabralb JMS, Fonsecab LP: The influence of culture conditions on mycelial structure and cellulose production by Trichoderma reesei rut C-30. Enz. Microbial Technol. 2000, 26: 394-401.

11. Etabarian HR: Evaluation of Trichoderma isolates for biological control of charcoal stem rot in melon caused by Macrophomina phaseolina. Journal of Agricultural Science and Technology 2006, 8: 243-250.

12. Eckert JW, Ogawa JM: The chemical control of postharvest diseases: deciduous fruits, berries, vegetables and root/tuber crops. Annu Rev Phytopathol. 1988, 26:433-469.

13. Elad Y, Chet I, Katan J: Trichoderma harzianum: A biocontrol agent of Sclerotium rolfsii and Rhizoctonia solani. Phytopathology, 1980, 70:119-121.

14. Elad Y, Chet I, Henis Y: Degradation of plant pathogenic fungi by Trichoderma harzianum. Canadian J. Microbiol, 1982, 28: 719-725.

15. Ellis MB: Dematiaceous Hypomycetes. Commonwealth Mycological Institute, England. 1971, pp. 508.

16. Ewulo BS, Ojeniyi SO, Akanni OA: Effect of Poultry manure on selected soild physical and chemical properties on growth, yield and nutrient status of tomato. Journal of Agricultural Research. 2008, 3(1):613-616.

17. Feng W, Zheng XD: Essential oils to control Alternatia alternata in vitro and in vivo. Food Control. 2007, 18, 11261130.

18. Gilman JC: A manual of soil fungi. IOWA State Uni. Press. Ames. 2008, pp.382.

19. Hadar Y, Chet I, Henis Y: Biological control of Rhizocotonia solani damping-off with wheat bran culture of Trichoderma harzianum. Phytopathology. 1979, 69:64-68.

20. Henis Y, Chet I: Microbial control of plant pathogens. Adv. Appl. Microbiol 1975, 198:85-111.

21. Intana W, Suwanno T, Chamswarng C, Chantrapromma K, Ngamriabsakul: Increased efficacy for controlling Anthracnose of chili using antifungal metabolites from mutant strains of Trichoderma harzianum. Thai Journal of Agricultural Science 2007, 40(1-2), 65-72.

22. Kakde RB, Chavan AM:. Antagonistic properties of Trichoderma viride and Trichoderma harzianum against storage fungi. Elixir Appl. Botany, 2011, 41: 5774-5778.

23. Lee PJ, Lee S, Kim CS, Son JH, Song JH, Lee KY, Kim,HJ, Jung SJ, Moon BJ: Evaluation of formulations of Bacillus licheniformis for the biological control of tomato gray mold caused by Botrytis cinerea. Biological Control 2006, 37: 329-337.

24. Mukherjee PK, Thomas P, Raghu K: Shelf-life enhancement of fresh ginger rhizomes at ambient temperatures by combination of g-irradiation, biocontrol and closed polyethylene bag storage. Ann Appl Biol. 1995, 127:375-384.

25. Nagamani Tagaram, Ammana Sabitha Rani, Amballa Hindumathi, Bhumi Narasimha Reddy: In vitro evaluation of Trichoderma viridi and Trichoderma harzianum for its efficacy against Alternaria alternate, the leaf spot pathogen on Senna plant. Journal of Pharmacy and Biological Sciences 2015, 10: 145-147.

26. Papavizas GC: Trichoderma and Gliocladium: Biology, ecology, and potential for biocontrol. Ann. Rev. Phytppath1985, 23: 23-54.

27. Prince L, Raja A, Prabakaran P: Antagonistic potentiality of some soil mycoflora against Colletotrichum falcatum. World Journal of Science and Technology 2011, 1(4): 39-42.

28. Schirmbock M, Lorito M, Wang YL, Hayes CK, Arisan-Atac I, Scala F, Harman GE, Kubicek CP: Parallel formation and synergism of hydrolytic enzymes and peptaibol antibiotics, molecular mechanisms involved in the antagonistic action of Trichoderma harzianum against phytopathogenic fungi. Appl. Environ. Microbiol. 1994, 60: 4,364- 4,370.

29. Stevens C, Khan VA, Lu JY, Wilson,CL, Pusey PL, Igwegbe CK., Kabwe K, Mafolo Y, Liu J, Chalutz E, Droby S: Integration of ultraviolet (UV-C) light with yeast treatment for control of postharvest storage rots of fruits and vegetables. Biological Control. 1997, 10: 98-103.

30. Schena L, Ippolito A, Zahavi T, Cohen L, Nigro F, Droby S: Genetic diversity and biocontrol activity of Aureobasidium pullulans isolates against postharvest rots. Postharvest Biology and Technology 1999, 17: $189-199$.

31. Skidmore AM, Dickinson CH: Colony interaction and hyphal interference between Septoria nodorum and phylloplane fungi. Trans. Br. Mycol. Soc. 1976, 66: 57-64.

32. Tomkin and Trout (1931). Pricking by Entomological pins (C-Dass Gupta and Mandal: 1989).

33. Watanabe T.:(2002). Pictorial atlas of soil and seed fungi: Morphologies of cultured fungi and key to species. (2nd ed.), CRC Press. Boca Raton, Florida, USA, pp. 504.

34. Wener ZH: 2008. Importance of the tomato. Available at http://agrisupportonlive.com/Article/importance of the tomato html. Date accessed January, 21st 2009.

35. Wilson, C.L., Franklin, J.D. and Pusey, P.L. Biological control of Rhizopus rot of peach with Enterobacter cloacae. Phytopathology. 1987, 77:303. 